\title{
Muslim Women and Sharia Implementation in Northern Nigeria: An Overview of Fomwan
}

\author{
Aisha Balarabe Bawa \\ http://dx.doi./org/10.4314/ujah.v18i1.8
}

\begin{abstract}
The status of Muslim women in the contemporary society has generated a lot of controversies and still generates serious debates and discussions in scholarly circle. Most scholars are of the views that Muslim women were subjugated, oppressed, and confined to domestic life that excludes their participation outside the home. In the wake of controversial implementation of Sharia (Islamic law) in the governance of some states, the Federation of Muslim Women Association of Nigeria (FOMWAN) served as an agency through which Muslim women speak as well as demonstrate that the implementation of Sharia is the greatest weapon against male domination. This paper examined the role of the FOMWAN in challenging the patriarchal ideology that is deeply rooted in the society. The paper argued that the activism of the organization was instrumental in the enlightenment and education of women especially on their rights. As such Muslim women of many different levels of educational attainment have become increasingly active in the organized articulation and pursuit of their interests and their rights under Islamic law.
\end{abstract}

Keywords: Islam, Women, Right, Sharia, FOMWAN 


\section{Introduction}

Islam is often seen as restrictive in terms of women participation in social and economic activities outside their home. In western societies, the mere mention of "women and Islam" triggers a chain of thought, which includes buzzwords like "veiling, oppression and subjection." Islam appears to be a patriarchal, authoritarian system, which is endured by women, but in which they have no say. Barbara and Creevey argue that "throughout West Africa, Islam has had the greatest impact on women's lives among those who were converted earliest and who were relatively isolated for centuries thereafter from with other culture."1 Suggesting that the longer Islam is present the more it will annihilate pre-Islamic customs favourable to women and the more subordinated women will become.

To the contrary, many Muslim scholars tend to dismiss this claim and deny that Islamic tenets on women are oppressive. They counter-pose the indignity women are suffering in societies of other regions with the advancement of women, as permitted in Islam and conclude that Islam lays their true liberation. Amina Wadud denies the claim that Islam established a patriarchal society or female subordination. ${ }^{2}$ One of the argument pointed out was that long before other civilizations revolved the issue of whether or not women had souls or should be entitled to basic rights, Islam gave rights and freedoms that were considered revolutionary to women more than hundred years ago. ${ }^{3}$ Islam as a religion has a comprehensive package of rights for women which includes the right to enter into contracts and legal agreements; the right to earn an income and dispose her property as she wishes, the right to express her opinions on all issues private or public; the right to education; the right to inherit and be inherited by her next of kin; 
the right to contribute to the development of the society in all spheres. ${ }^{4}$ For instance, Lemu writes that:

It is interesting to note that in the 1860s for the first time in western world, in Britain in particular, a series of laws known as married women property act were passed. For the first time in the west, the right of married women was recognized to dispose of their property without the control or permission of their husbands. That right was established about 13000 years earlier by Islamic law.

Furthermore, in order to strengthen women economic, position, Islam gives emphases to the necessity of paying dowry to a woman as a matter of right. Islam therefore, recognized the right of women in the process of redistribution of wealth. However, during this period of early Islamization, subservience to husbands was emphasized at the expense of obedience to God. Men used the opportunity to over burden women with domestic chores like gathering of firewood, cooking, washing of clothes and the like. Women were also used on farms for manual labour which uplifted the social status of men.

From the beginning of the $19^{\text {th }}$ century therefore, there was a dramatic change in the nature of government for much of Hausaland. Shehu Usman Danfodiyo organized a religious movement to reinvigorate Islamic values and established a sociopolitical system that would protect Islamic moral values from disintegrating. The Sokoto caliphate was consequently established in the first decade of the $19^{\text {th }}$ century. Out of this context, scholar Shehu Usman Danfodiyo emerged. From 1804 to 1812 throughout much of Hausaland a caliphate was established in Sokoto. The establishment of Sokoto caliphate brought substantial changes in the lives of the Muslim Hausa women. For instance, it was deemed 
in appropriate for women to hold public office, and they were increasingly secluded in their homes. Free Muslim status became associated with seclusion and veiling after the Jihads, women began disappearing from agricultural work. This paper examined the activism of Muslim women organization FOMWAN and Sharia implementation in Northern Nigeria.

\section{Patriarchy and Cultural Practices in Northern Nigeria}

The Northern Nigeria is traditionally patriarchal society where rigid interpretations of Islam and powerful cultural traditions interact to undermine the rights of women. This culture of patriarchy is a strong determinant of male dominance over female and as a result girls' educational opportunities are usually guarded by patriarchal attitudes. Local and fundamentalist patriarchies conflate local historical practice with religious dialogue and use subversive interpretations of Islamic law to relegate women to their limited definition of the domestic sphere. ${ }^{6}$ The belief that the woman is inferior and divinely ordained to be a man's subordinate with passive social roles, readily offers a latent justification for practices like gendered educational segregation, career discrimination, polygamy, and political marginalization.

The practice of purdah or seclusion also determines the extent of women's visibility and mobility in public spaces. Apologies of women inferiority often leverage on religious traditions to legitimize their opposition to female education, and active social roles for women. The issue of early marriage is another cultural practice in Northern Nigeria. The society believes it is the most important thing in the life of a girl. The women often do not have a say in family planning. They are to submit to their husband's desires for sex and give birth to as many children as they can. They cannot make the decision as to the number of 
children they want to bear. ${ }^{8}$ The advent of Islam had dual impacts on women's status in the region. On one hand, Islam strengthened the existing patriarchal nature of the society by entrenching men supremacy and emphasizing women submission. On the other hand, Islam encouraged women education and literacy. Various organizations have used a diverse set of tactics to break this patriarchal and misinterpretation of Islam to justified women's subordination. The Muslim women's movement is a natural outcome of the situation they have been forced to deal with and the debate this creates is in many ways valuable in itself.

\section{Breaking the Barriers: Women's Movement}

Women in Nigeria irrespective of their ethnic or religious background or geographical origin are thoroughly dissatisfied with the situation they found themselves as a result of their sex. Many of them employed different strategies to change and improve their situation. They often do this as members of women's organizations of which many, both secular and religiously oriented, exist in Nigeria. Muslim women tend to articulate their dissatisfaction with their social status, far-reaching changes which can improve the status of women run against the interests and ideological conceptions of conservative and politically influential Muslim men. ${ }^{9}$

In order to be effective in their endeavours to effect change, Muslim women consequently have had to stress their attachment to Islam. Northern Nigeria historically was a region comprised of Hausa kingdoms, or city-states, from 1804 - 1808, Islamic scholar Usman Danfodio led a successful Fulani Jihad against the Hausa city-states in today's Northern Nigeria. This jihad initiated the transformation thereafter of the poleis into Islamic societies. The Jihad brought new legal and political institutions in the form of a 
federation between a caliphate based in Sokoto, and new emirates to transform the old Hausa political and social structures. ${ }^{10}$ Since the establishment of the Caliphate in the nineteenth century, northern Nigeria has become the largest and most influential Islamic tradition in sub-Saharan Africa. This rich history gives Muslim women from the north a voice that is distinct from western feminist movements and sometimes contrary to them.

In declaring the war in 1804, Usman Danfodio and his followers called for the purification of Islam against the syncretism that was widespread in Hausa society and preached against the abuse of power in courts of Hausa rulers. In keeping with wellestablished traditions of the Muslim world, Fodio's numerous writings and teachings, include women. One of his poems described what he called "the oppressive custom of mature married men":

They fail to address, house and feed their wives adequately, they show favouritism between one wife and another and make unwise and hastly marriages without due thought... they revile their wives... and beat them excessively... They do not educate them and if they divorce them they spread malicious tales about them thereby ruining their chances of re-marriage - others refuse to divorce unhappy wives... My goodness! All these things are evidence of ignorance. ${ }^{11}$

As in other parts of West Africa, the Sufi and Maliki scholars have had a tradition of upholding Muslim women activism as they supported women spiritual edification to the highest level. Education and literacy have been hallmarks of Islam since its inception. Any society that impedes equitable access to salvation by controlling or limiting who can get an education eschews the tenets of Islam. ${ }^{12}$ 
So for the Qadiriyya community to which Usman Danfodio belonged, education of women was paramount. This has been exemplified by Shehu's daughter Nana Asma'u (1793-1864). She was a prolific author, popular teacher and renowned scholar and intellectual. Boyd and Mack stated that "Asma'u's main work was in the education of women in order to equip them to bring up the next generation of children within the desired ideological framework. ${ }^{13 "}$ The greatest of Asma'u's contribution which signifies her political and intellectual sophistication is the 'Yan taru movement, a movement which was the backbone of her teaching philosophy and the soul of her reform strategy hence the genesis of the Nana Asma'u tradition. In Eastern Nigeria, women's movement emerged when colonial administration gave warrant chiefs the power to collect taxation over men and women, women resisted to show their displeasure over colonial policies. The 1929 Aba Women riot was one of such protest organized by women against colonialism.

Scholars studying the colonial period in Africa have traced the presence of what we could call an indigenous feminist consciousness in various women's movements across the continent. Nina Mba's path breaking book of 1982, Nigerian Women Mobilized, demonstrated the activism and political engagement of eastern Nigerian women. She stress that "the women's war was very much a feminist movement in the sense that the women were very conscious of the special role of women, the importance of women to society and the assertion of their rights as women vis-à-vis the men. ${ }^{14}$ As it happened in SouthEastern Nigeria women in South-Western part of the country equally took the initiative in organizing political action against the British system of indirect rule which conferred unprecedented power on the traditional ruler and excluded them from 
participating in decision making. Notable among these women was Mrs. Funmilayo Ransome Kuti who led the formation of the Abeokuta Women Union (AWU). The objective of AWU was to unite women in order to defend, protect, preserve and promote their social, economic and political rights. ${ }^{15}$

From the foregoing, it has evidently show that irrespective of religious background or ethnicity women in Nigeria employed different strategies to resist patriarchy reinforce by cultures and colonialism. Although the Aba women riot and the AWU protest yield positive results of extent that certain reforms and measures were taken by the colonial administration to ensure women education and representation in the traditional leadership, the northern Nigerian women continued to face serious challenges on the question of what consist of their basic rights.

\section{Muslim Women and the Question of Right}

Modern development has emboldened women to fight for rights similar to their male counterparts and to denounce any seeming legislation that tends to play down on their freedom. According to Aysu,

In Islam, women have the same basic rights and freedoms as men have, and there is no kind of restriction to their rights and responsibilities. Everyone whether they are man or woman has the right to work, to trade, and to have a public job, provided they follow the basic Islamic principles and rulings and show respect for the general rules of ethics. ${ }^{16}$

They both share religious responsibility in legal matters, and both have basic rights and freedom. However, the social and cultural milieu, and especially the patriarchal family structure were the 
dominant factors in determining the position of women. Any fair investigation into the history of the Islamic civilization will surely find how Islam recognized the prominent role of women; gave them socio-economic rights and promoted inclusion of the discriminated, oppressed and excluded women in the society. In pre-Islamic Arabia, women were not allowed to own property or terminate marriage. Recognizing the prominent role of women in the society, Islam liberated women by giving them roles, duties and rights. A glimpse of the situation of the deprived and discriminated women at that time is provided by Abd Fotouh Razi in his book Interpreting the Qur'an, cited in Rajavi, Razi writes:

During the Age of Jaheliat (ignorance) and early Islam, it was customary when a married man died for one of his male heirs to place a piece of cloth on the widower or on her tent, thereby becoming her owner. The woman would be left on her own without any rights or income, until such time as the man would seek compensation from the woman for letting her go, or would keep her as a slave until he die. $^{17}$

The condition of women at that time was terrible. Women had no right to own property, were supposed to be the property of the man. Prophet Muhammad, however, by instituting rights of property ownership, inheritance, education and divorce, gave women certain basic safeguards. Muhammad granted women rights and privileges in the sphere of family life, marriage, education and economic endeavours that help improve women's status in society. ${ }^{18}$ Islam recognizes that education determines the socio-economic development of a society hence allows women to get education. The Prophet says that seeking knowledge is a 
mandate for every Muslim man and woman. This includes knowledge of the Qur'an and Hadith as well as other knowledge.

Women in Islam are allowed to earn money through business or work and no one has any claim on their earnings including their husbands. Islam promoted inclusion by giving women the following economic rights:

- The Islamic Shari'ah recognizes the full property rights of women before and after marriage.

- Greater financial security is assured for women. They are entitled to receive marital gifts, to keep present and future properties and income for their own security.

The Prophet prepared the ground for women to take part in their own liberation and fashion their destiny. The revolution which began by banning the burying of live girl children, subsequently recognized women's economic independence. ${ }^{19}$ The Qur'an in this regards clearly states: "to men is allotted what they earn and to women what they earn". The Muslim woman has the privilege to earn money, the right to own property, the right to enter into legal contracts and the right to manage all of her assets in any way she wants. She can run her own business and no one has any claim on her earnings including her husband. In addition, in the early Islamic history, women not only participated in various aspects of their society's public sphere. They also had the right to be elected to political offices. The appointment of a woman to oversee the affairs of the market place by Hazrat Omar, the second caliph, also sheds light on the inclusive nature of Islam towards women in the society. However, in spite of the fact that Islam encourages women to be educated, developed and progressive, yet the males do not give them ample chance to develop themselves because of patriarchal tradition. As such, Muslim women supported by male 
as well as female Islamic scholars, today use Islamic arguments to show that many practices which discriminate against women are oppressive and reflect cultural malpractices or cultural prejudices rather than Islamic truths.

\section{FOMWAN and the Sharia Re-introduction}

The Federation of Muslim Women Association of Nigeria (FOMWAN) is one of the largest Muslim women's organizations in Africa. It is a federation of over 500 affiliates across Nigeria established in 1985. The objectives of FOMWAN are clearly reformist as they seek to promote understanding and practice of the teachings of Islam, encourage Muslim women to establish groups throughout the country for educational purposes, establish a framework for national cooperation and unity among Muslim women associations, provide a forum for Muslim women's views to be expressed at national and state levels. ${ }^{20}$

These women hypothesized that for women to excel in their religion they need to be educated. Such education should however not be limited to religious education which is already widely accepted by Muslims. The reform process in Islam is thus for Muslim women reformers, an opportunity to create a space of freedom for themselves within what is essentially a system hostile to women. The reform process (Sharia) enables them to advance claims that: women constitute a special category constructed by Islam; female demands have to be confined within the boundaries set up by religious tradition and the legal, theological and political framework. $^{21}$

In Nigeria, Sharia has been in existence for several centuries, since the pre-colonial era, when the Sokoto Caliphate was administered according to Muslim laws. The Islamic legal system (Sharia) has been drawn to be a major component of Islam. Sharia is the sum 
total of the life-example (Sunna) of the Prophet Muhammad and his companions, as narrated through the Tradition (Hadith) literature, codified through the discussions of jurisprudence and manifested from a practical point of view through the medium of the Fatwa (legal opinion). ${ }^{22}$

The responsibility of Muslim women does not, like many are apt to believe, end up in the home. This wrong impression has been propagated and even given semblance of religious support. It is semblance because neither the Qur'an nor the Sunna really support the relegation of women. This was the case in Hausaland before the Jihad of Shehu Usman Dan Fodio. For Shehu to pull the depraved Hausa society out of the abyss of its rot and revitalized it, he devoted at least three of his works to emphasizing the rights of women to education and freedom of movement. On the former, no limits were imposed while the latter was conditioned. The ideas of rights made women eligible for formal education, including business education. Shehu was very blunt about the literacy and ignorance of Hausa women for which he squarely blamed men. According to him:

Men treat these beings like household implements which became broken after long use and which are then thrown out on the dung heap. This is an abominable crime! Alas! How can they shut their wives, their daughters and their captives in the darkness of ignorance while daily they impact knowledge on their students. ${ }^{23}$

Therefore, women education was given prominence during this period which influenced the emergence of Nana Asma'u, the daughter of Shehu Usman Danfodio. She was a scholar, poet, commentator, and socio-cultural engineer whose mountain of knowledge cannot be equalled to her contemporaries. She was 
active in politics, education and social reforms. She was a prolific author, popular teacher and renowned scholar and intellectual. ${ }^{24}$

Asma'u established a cadre of literate, itinerant women teachers (Jajis) who disseminated her instructive poetic works among the masses. Trained by Asma'u, these women were extension teachers using Asma'u's works as lesson plans and mnemonic devices through which they instructed secluded women in the privacy of their homes. The greatest of Asma'u's contribution which signifies her political and intellectual sophistication, is the 'Yantaru Movement, a movement which was the backbone of her teaching philosophy and the soul of her reform strategy. With this heritage in mind, it is easy to see why after independence in 1960 Northern Nigerian Muslims emphasized repeatedly the need to implement Sharia. Since the demise of the Caliphate at the beginning of the 20th century, women have been allowed to sink below the level that Shehu Usman found them.

To this regard, in the mid-1970s, during the debate for the promulgation of the 1979 constitution calls came from some Muslim members of the constituent Assembly for the incorporation of Sharia law. ${ }^{25}$ Specifically, the Sharia court that was demanded at this stage was to deal with issues like: (i) the sharing of inheritance among members of a family (which women seems to benefit), settling marital disputes; and settling the issue of the custody of children and other similar civil matters. However, for most of the period from independence in 1960 until 1999, Nigeria was under military rule which make it difficult for the Sharia law to be effectively implemented.

In 1999, following elections held in May, a civilian administration came into being. In October of 1999, the state of Zamfara instituted the first Sharia based system of governance. The governor of Zamfara, Alhaji Ahmed Sani Yerima, led the 
movement to introduce Sharia. Shortly after Sharia was implemented in Zamfara, several other northern states considered following the same route. Twelve of the nineteenth northern states in Nigeria had declared Sharia as the legal code. This development altered the state of affairs in the region. For instance, it led to the modifications of the penal codes of these states which have engendered wide social, religious, political, educational and psychological ramifications. Particularly, its implication on the lives of women has been enormous.

The re-introduction of Sharia in northern states has carved out a religious field with different players and actors. The Federation of Muslim Women's Associations of Nigeria (FOMWAN) is one of those actors. The Muslim Women under the Umbrella of FOMWAN challenges the held notion that these women, though highly educated and highly influential in their own rights challenges that notion by showing how formidable Muslim women can take up women's issues. FOMWAN support for Sharia implementation was because it gives reason for manoeuvre for women. The room to manoeuvre provided by Islamic reform is reinforced by its emphasis on the right to individual interpretation of the Qur'an and the hadith or Ijtehad (independent reasoning) which permits women rights to (re) -interpret Islamic law and challenge dominant patriarchal interpretations that dis-empower women. ${ }^{26}$ FOMWAN claimed that one of the principles of Islam is the search for knowledge which must be sought after from the cradle to the grave. They also seem to realize that for a successful implementation of Sharia that would be acceptable to the masses, the governments have to come up with programs that are directed towards encouraging female education.. With the introduction of female educational programs, some of the states have experienced high enrolment figures since the implementation of Sharia. ${ }^{27}$ For 
example, between 1999 and 2006, Kano state established up to 104 new female schools all over the state.

Likewise, there has been a great deal of transformation of educational institutions in the states to meet up with modern standards. These include the renovation of existing schools and the establishment of new ones; the provision of modern facilities in some of the schools especially in Zamfara and Kaduna states, the establishment of separate educational boards that would monitor the activities of new schools, collaboration with non-governmental organization such as UNESCO and Girls Education Project (GEP) in several of the Sharia States and the provision of incentives to students by the government. ${ }^{28}$ In Zamfara State, for instance, the program "The Journey to our Greatness" was introduced with the aim of improving on the education of women and girls. This program entailed an overhauling of female education are brought under one umbrella for effective implementation of all programs initiated for women during this program. Another program introduced by the state still with focus on women is "Bridging the Gender Gap, Focal primary schools in Zamfara State". Its aim was to provide model schools where girls could be closely monitored and trained according to Muslim ethics before they entered tertiary education.

In Kano State, a similar program called "Societal Reorientation on Street Hawking" (A daidaia Sahu-adalilin tala in Hausa) was introduced, with the particular aim of putting an end to street hawking prevalent among young girls in all parts of northern Nigeria. Street hawking is one of the factors responsible for female being kept away from school as their mothers rely on them for petty business in homemade snacks. ${ }^{29}$ A more widespread program introduced in both Zamfara and Kano States, which also exists in other parts of the Sharia states, was the establishment of Women 
Continuing Education Centers (WCECs) whose principal objective was to provide educational opportunities for women. The centers targeted women who had dropped out of school to get married. So it provided them the chance to continue their education in their capacity as married women and also as mothers and first teachers of children.

The low level of education among Muslim women in Nigeria and particularly northern Nigeria is that FOMWAN sought to tackle from its inception 27 years ago. Therefore, FOMWAN considered the re-introduction of Sharia in the 12 northern states as an opportunity to use for the retention of girls in school as well as the provision of continuing education for women.

\section{Conclusion}

The paper examined the significant role played by FOMWAN in improving the lives of Muslim women during the re-introduction of Sharia in northern Nigeria. There is no doubt that in the last decade of the 20th century, Sharia and its implementation have been at the forefront of the demands of most northern states in Nigeria. The Sharia was the basis for their widespread of Islam especially as exemplified by Shehu Usman Danfodio. The Caliph in Sokoto continues this tradition not until the British conquest of the caliphate in 1903. With this heritage in mind it is easy to see why in 1999 northern Muslims (especially FOMWAN) supported the need to implement Sharia. It has that despite the national and international condemnation of the Sharia over the conviction of some poor women by Sharia Courts for adultery and the sentencing of these women to death by stoning. Sharia was widely accepted by the Muslim organization (FOMWAN).

The Qur'anic injunctions on the rights and privileges of women are believed to have granted women equal access to all 
forms of education under Sharia. However, due to cultural practices and the fact that the law is interpreted by men, Qur'anic verses and injunctions are often read from a male stand point that keeps the dominant both within the religious and the cultural nomenclature. Women have, therefore, been made to comply with such interpretations which though constitute symbolic violence for them and their rights to choose what is good are viewed by these women as authentic and ideal. Through the statistics provided and series of programs of intervention by the Sharia states, the paper has shown that through agitation of FOMWAN emphasis on female education in Sharia states has improved, which led to large female enrolment figures.

\author{
Aisha Balarabe Bawa \\ Department of History \\ Usmanu Danfodiyo University \\ Sokoto \\ ayshabawa@gmail.com
}

\title{
References
}

Beverly, M and Boyd, J. (2000) One Woman Jihad: Nana Asma'u, Scholar and Scribe. Indiana University Press, USA.

Bossaller, A. and Leimeier, R. (1994). "Radical Muslim and Male Politics in Nigeria" in Reh, M. and Ludwar-Ene, G, (eds.),

Gender and Identity in Africa. Litverlag, Munster.

Karunwi, A. (2004), "The Role of NGOs in Gender Awareness" in Akinboye, S.O, (eds.), Paradax of Gender Equality in Nigerian Politics, Concept Publications, Lagos.

Wadud, A. (1999). Qur'an and Women: Rereading the Sacred text from a Woman's Perspective. New York: Oxford University Press. 
Bawa, A.B. (2012). "Gender Issues in the Literacy Works of Sokoto Jihad Leaders of the 19th Century: A Cursory Look at Shaykh Uthman Ibn Fodio", Paper Presented at the 7th National Conference on Literature in Northern Nigeria, organized by Bayero University Kano, in Conjunction with Kwara State University, Maleti, held at Musa Abdullahi Auditorium, BUK on 3rd - 6th December.

Kani, A.M, (1988). The Intellectual Origin of the Islamic Jihad in Nigeria. Nigeria: Alhoda.

Adeola, A. I. (2012). "The Perspectives of Tradition and Religion in Northern Nigeria Women: Zaynab Alkali's the Virtuous Woman" in Yerima Ahmed and Saeedat Aliyu (eds) Gender Politics: Women's Writings and Films in Northern Nigeria, Ibadan: Kraft Books Limited.

Arinde, S. T. (2010). "Repositioning Women for the Promotion of Global Peace: ACase Study of the Wives Revolt and Queen Ghasengeh", Ilorin International Conference on African Literature, Obafconfaf Book of Proceedings. $1^{\text {st }}-4^{\text {th }}$ April.

Mack, B.B and Boyd, J. (2000). One Woman's Jihad: Nana Asma'u Scholar and Scribe. Indiana: Indiana University Press.

Barbara, C.M.(1998). Gender and Religion in Hausaland. In Herbert L. Bodman and Nayereh Tohidi (eds), Women in Muslim Societies: Diversity within Unity, USA: Lynne Rienner Publishers.

Johnson, C (1982). "Grassroot Organising: Women in Anticolonial Activity in Southwestern Nigeria”, African Studies Review, vol. 25, no. 213. 
Ukeje, C (2004). "From Aba to Ugborodo: Gender Identity and Alternative Discourse of Social Protest among Women in the Oil Delta of Nigeria" in A. Signe, B.K. Chacha, G. Amanda, J.Ahikire, A. Ogundipe, C. Pereira, P. Mansah, C. Ukeje, F.A. Yieke (eds) Gender Activism and Studies in Africa. CODESRIA.

Danfulani, C. (2012). "The Re-Implementation of Sharia in Northern Nigeria and the Education of Muslim Women, 1999 2007". Ph.D Thesis, University of Bayreuth.

Siddiqui,F (2015). "Exclusion, Women's Rights and Inclusive Islam" In S. Murtazu (ed.), Understanding Women's Issues at Feminist Standpoint. http://works.bepress.com/ professorvibhutipate/57 retrieved 8/11/2015.

Aysu, G.G. (2006), "Women in the 20th Century: Modernity, Feminism and Islam in Turkey". M.A. Dissertation, Faculty of Graduate School, the University of Texas, Arlington.

Kari, B. (2002). "Legacies of Colonialism and Islam for Hausa Women: An Historical Analysis, 1804-1960".Women and International Development Michigan State University.

Lemu, A. (1992). Misconception About Islam, Minna, IET Publication.

Mba, N. (1982). Nigerian Women Mobilized: Political Activism in Southern Nigeria, $1900-1965$. Berkeley, University of California Press.

Olarinmoye, O.O. (2013). Negotiating Empowerment: Women and Identity in Nigeria. International Journal of Sociology and Anthropology, vol. 5(3):59-65.

Sada, I.N. (2007). "The Making of Zamfara and Kano Panel Codes". In Ostien, P. (ed.), Sharia Implementation in Northern Nigeria, 1999-2006: A Source Book. Ibadan: Spectrum Books Ltd.

Hodgking, T. (1975). Nigerian Perspectives: An Historical Anthropology. London. 